\title{
Food Chains and Ecosystem Services through a Resilience Lens
}

\author{
Rosanna Salvia ${ }^{1}$ - Giovanni Quaranta ${ }^{1 *}$ \\ ${ }^{1}$ University of Basilicata - Italy (campus di macchia romana, 85100, Potenza - \\ Italy \\ *Corresponding author: giovanni.quaranta@unibas.it
}

\section{Abstract}

Agro-food chains are coupled social-ecological system (SES). The actors involved in the agro-food chain (farmers, processing, distribution and retail industries, consumers), take decisions that feed back into the different components of the food chain as well as into the agroecosystem within which they are embedded. In the light of global warming and limited natural resources, it is imperative to build resilient agro-food chains that ensure food security and the integrity of the ecosystems. Resilience is the ability of a system to maintain its structure and functions and to reorganize itself in the face of the disturbance. Using a resilience thinking approach, this chapter proposes a framework to analyse the links between the mechanisms put in place within an agro-food chain to foster resilience and their impacts in terms of ecosystem services and wider socioeconomic effects on the socio-ecological system as a whole. The framework has been tested in a typical Mediterranean context, analysing an olive oil chain over the last 60 years.

Key words: Agro-Food chain resilience, Socio Ecological Systems, Ecosystem Services, olive farming

\section{Introduction}

The last decades have seen profound structural changes in agriculture, agro-food systems and rural areas as a whole. If we consider European agriculture, the intensification of production in some specific areas has 
led to the marginalization of other areas, generally with less favourable production conditions and / or more distant from markets (Knickel et al., $2013,2018)$. In a review of the main land and farming system dynamics and drivers in the Mediterranean Basin, Debolini et al. (2018) describe the abandonment of agricultural areas as the most prominent on-going trend, whose drivers are due to depopulation and population ageing; low profitability of farming, the industrialization of processes and the increase in input prices. Closely connected to geographical disparities, there are increasing "tensions" within the agro-food chains where the agricultural component is exposed to internal pressures that arise from asymmetric price transmission, changes in market relations and internal trends such as upstream (e.g. input suppliers) and downstream (e.g. retail) concentration and market integration. Furthermore, increasing complexity and changing consumer demands also affect the internal organization of the agro-food chain (Hubeau et al., 2017; Campbell, 2005; Potter and Tilzey, 2005).

These phenomena have profoundly altered the quantity and quality of functions performed by agricultural ecosystems. Beyond their role of producing food and fibre, agricultural systems play other, potentially essential roles in the socio-ecological system they are part of. Socio-cultural and bio-physical functions such as ecological integrity, water resource sustainability, livelihood maintenance, nutritional viability, and food security, i.e. the wide range of public good-type services produced by multifunctional agricultural systems, constitutes important socio-economic resources for the rural economy (Hodbod et al., 2016; Costanza et al., 1997; Huang et al., 2015; Huylenbroeck et al., 2007).

A large number of studies have also investigated the social and economic effects related to the supply of private and public good-type ESS in agricultural ecosystems. The main effects which have been identified are: occasions for added value creation (Dissart and Vollet, 2011); the creation of niche-market opportunities for local and quality products (Tempesta et al., 2010), opportunities for rural employment (Dissart and Vollet, 2011); maintenance/stability of the rural population (Schaller et al., 2018); creation of local investments (Schaller et al., 2018); enhanced recreational opportunities (Sharpley and Vass, 2006; Rodríguez-Entrena et al., 2017), 
enhanced quality of life and the viability of rural crafts and traditional skills (Sharpley and Vass, 2006). In the Mediterranean basin, for example, the area's long history of agriculture has produced an extraordinary variety of land uses and landscapes, which in some cases had dramatically altered the local environment (e.g. terraces and irrigation channels, hedges and agro-silvo-pastoral systems) (Pinto-Correia and Vos, 2004). Many traditional Mediterranean agricultural systems combine food production with the provision of other ecosystem services. For example, silvopastoralism and agroforestry are known for their regulation of soil erosion and maintenance of soil fertility in combination with food production (Torralba et al., 2016). Traditional farming systems play a significant role in supporting biodiversity (Bugalho et al., 2011). Many of these traditional agricultural systems produce the highest quality agro-food products, which are recognized by the EU through the PDO and PGI labels (Fondazione Campagna Amica, 2018). Under the general reconfiguration and restructure of the agro-food chains, these agricultural systems have responded by favouring simplification, aimed at increasing agricultural yields and gross margins (Pinto-Correia and Vos, 2004).

Resilience relates to the ability of a system to maintain its structure and functions and reorganize in the face of disturbance (Walker et al., 2004), including the capacity to recover from unexpected shocks and adaptation to ongoing change (Biggs et al., 2015). Although it is based in ecology, the theoretical constructs of resilience are assistive in understanding the dynamics and functions of many types of social-ecological systems, which include agro-food systems (e.g., Babu and Blom 2014, Darnhofer 2014). Understanding resilience will be crucial because agro-food systems provide essential life-supporting services and are currently facing an array of potentially existential threats (population growth, climate change, degradation of natural resources among the others) (Himanen et al., 2016; Vroegindewey and Hodbod, 2018).

However, efforts to understand resilience mechanisms have often focused on only a part of the agro-food system (most often agricultural production), while neglecting account for the whole system and the internal interactions between components (Tendall, 2015). 
In light of these considerations, the aim of the chapter is to propose a framework to analyse the links between the mechanisms put in place within an agro-food chain to foster its resilience and the effects on the ecosystem services that the agro-food ecosystem is able to provide. The framework, therefore, intends to look beyond the agricultural sector to include the role played by the other actors and components of the food chain. An empirical analysis conducted in a Mediterranean context, predominately characterized by an olive oil chain, shed light on the drivers underlying structural transformation (abandonment and intensification) and substantial change in the organization of the value chain, in a bid to allow the system to compete in an increasingly global context.

The rest of the chapter is organized as follows; the first section analyses the conceptual paradigm of resilience and its application within agroecosystems and agro-food chains; the next section describes the proposed framework. The chapter ends with an application of the framework, related key findings and some concluding considerations.

\section{Agroecosystem and Agro-food chain resilience}

Resilience thinking has its origins in ecology, with Holling, (1973), who showed the importance of resilience and defined it as the ability "to manage and cope with change", but has been increasingly adopted as an approach to understanding social-ecological systems (SES) (Adger, 2000, Carpenter et al., 2001, Folke et al., 2010), including agricultural and rural SES (see for example Darnhofer et al., 2014; Lamine, 2015; Scott, 2013; Salvia and Quaranta, 2015). Socio-ecological systems are understood as complex and integrated systems in which human beings should be considered part of nature (Berkes and Folke, 1998).

Cabell e Oelofse (2012), using the conceptual category of social-ecological system, define the agroecosystem as an ecosystem managed with the intention of producing, distributing and consuming food, fuel and fibre. Its boundaries encompass the physical space dedicated to production, as well as the resources, infrastructure, markets, institutions and people that are dedicated to bringing food to the consumers. The agroecosystem works simultaneously at many nested scales and hierarchies, where it is clear that farmers do not operate in a void and the decisions they make 
are largely based on external influences (Darnhofer et al. 2010b). In this respect, Darnhofer et al. (2016) highlight the importance of farmers' agency, the wider social forces that play influential roles, and the importance of a range of capacities: the capacity to conserve existing functions and structures (persistence), the capacity to deal with uncertainty through reorganisation and learning (adaptability), and the capacity to create a wholly new trajectory that involves a change in the very nature of the system (transformation).

In order to measure resilience within agroecosystems, Cabell e Oelofse (2012) propose 13 indicators, showing their importance within the adaptive cycle, i.e. the four phases of cyclical change that are characteristic of SES: growth/exploitation, conservation, release, and reorganization/renewal (Gunderson and Holling 2002, Darnhofer et al., 2010b). Adaptive cycles are nested (Gunderson and Holling 2002). This feature of hierarchical nesting has been termed panarchy (Gunderson and Holling 2002), which describes how interactions within and across scales can determine the overall dynamics of the system. System dynamics can be controlled by both top down and bottom up processes (Berkes e Ross, 2016). The focal scale for resilience analysis is the farm community because of the direct and complex social and ecological linkages that are present at this scale.

At a regional food system scale, Salvia and Quaranta (2015) use the adaptive cycle heuristic as a diagnostic tool to study dynamics of change in two regional agricultural sectors. Using a participatory approach, they show how the adaptive cycle can support the analysis of alternative management options taking in consideration the trade-offs among natural, economic and social capitals. In the same vein, Wilson (2010, 2012), through an analysis of economic, social and environmental capitals, reflects on the relationship between resilience and the multifunctionality of agricultural and rural spaces. Wilson examines the place-based characteristics that contribute to strong or weak resilience, and is able to even trace the temporal evolution of rural systems and the unfolding trajectories of contrasting development paths: relocalised low intensity rural systems, deagrarianised rural communities and superproductivist rural systems. Wilson et al. (2016) identify examples of suboptimal 'locked-in' develop- 
ment paths in rural systems highlighting the complex interrelationships between various lock-ins.

A specific literature stream, originated within the supply chain management disciplines, deals with the resilience of supply chain systems (Kamalahmadi and Parast, 2016). Although paying less attention to environmental and other sustainability issues (Bolwig et al., 2010), the importance of this analysis lies in the development of capacity to address disturbances affecting supply chains, at both the demand and supply level. According to Ponomarov and Holcomb (2009, p. 131) the supply chain resilience is "the adaptive capability of the supply chain to prepare for unexpected events, respond to disruptions and recover from them by maintaining continuity of operations at the desired level of connectedness and control over structure and function".

Stone and Rahimifard (2018) highlights how the concept of resilience when applied to agro-food chains tends to focus on optimising individual stages of a supply chain, which does not help prepare them to adapt to new or changing landscapes, nor does it take account of the risk that optimising one stage of the supply chain may be to the detriment of another. In response, the authors propose an adaptive definition of resilience that recognises that the complexity of cross-scale interactions in the system mean that system instability can be a permanent state rather than the response to a one-off shock and, therefore, resilience must be thought of as a continuous cycle of "conservation", "release", "reorganization" and "exploitation". The authors propose a framework that combines the ecological science understanding of adaptive systems and "panarchy", with resilience elements and strategies originating from Supply chain management literature. The framework proposes that parallels can be drawn between the four stages of the adaptive cycle (conservative, release, reorganisation and exploitation) and the four phases of a disruption, respectively (readiness, response, recovery and adaptation) (Ponomarov and Halcomb, 2009). Stone and Rahimifard (2018) identify 40 resilience elements and organize them into "Core" elements and "Supporting" elements. The authors argue that "supporting elements" are indispensable for the "core elements" and enable a better understanding of resilience along the whole supply chain, reflecting social and environmen- 
tal components of supply chains rather than only economic aspects. Linked to this is the need to design resilience strategies around the different phases of disruption in which a resilience element must be implemented.

\section{Unifying perspectives: bridging agroecosystem and agro-food chain resilience}

In an attempt to further develop the argument that resilience building needs to involve all actors in the agro-food chain for an agro-food system to maintain its multifunctionality, and therefore be able to guarantee the flow of ecosystem services, a unification of perspectives is required. Based on this assumption, and combining the reflections of Cabell and Oelofse (2012) and those of Stone and Rahimifard (2018), the characteristics that confer resilience to agro-food chains are outlined and organised according to the various phases of the adaptive cycle that the system moves through.

Release phase: The agro-food system components are able to retain the elements, both tangible and intangible, that come from the past and reuse them in the next phase of reorganization, avoiding the risk of locks-in (Wilson et al., 2016) (Path dependency). There is a diversity of system components, i.e. the chain maintains a sufficient degree of heterogeneity: for example, multiple type of farmers, processors, and/or distributors in terms of scales, production systems, capacities and skills, and other characteristics. Actors within the chain collaborate and work together to create benefits that could not be achieved individually. Information sharing and good levels of trust between the actors are all factors that help the system to reorganize itself more effectively and quickly. The degree of collaboration is strongly conditioned by the bargaining power within the agro-food chain. Functional to creating a collaborative climate is the degree of development of human and social capital, i.e. the strength and density of networks within the system. Visibility is another key element for agro-food chain resilience and corresponds to the ability to see structures, products and processes from one end of the chain to the other. This feature is influenced by the availability of an effective and efficient information flow along the chain, i.e. the possibility that information, 
such as trends in consumer tastes or the technology used by the competitors, reach the right actors at the right time.

Reorganization phase: at this stage resilience is closely linked to the capacity of the chain components to develop autonomous trajectories tight to local context (Socially self-organized), especially in terms of natural resources (Coupled with local natural capital). As in the previous phase functional and responsive diversity as well as human and social capital, combined with reflective and shared learning are key elements for developing resilience, learning from the past and experimenting with new ways of developing. To be resilient, the agro-food chain must show agility, i.e the speed / rapidity with which alternative options can be implemented to recover lost functionality or in response to changes in the competitive scenario or in consumer tastes.

Exploitation phase: The strength and number of connections within a system and between systems are able to determine the ability to adapt, transform and react to changes, thus affecting the degree of resilience of the system (Gunderson and Holling 2002). A high connection implies a diversity of relationships between components, while a low connection implies a lack; a strong connection makes a system rigid, while a weak connection gives it flexibility. In an agroecosystem, it is preferable to have a large number of weak connections. The appropriate connection is one in which, for example, farmers collaborate with multiple suppliers and many outlets, including consumers, rather than just one. The connection thus conceived is consistent with a high degree of functional diversity and response. At this stage it is important that the agro-food chain be characterized by a high degree of adaptability, i.e. the ability to adapt incrementally or completely transform itself in response to an evolving environment. To be able to do so, the "adaptability" of a supply chain also depends on the presence of "co-learning", i.e. joint learning at the system level, for which a high level of human and social capital is fundamental.

Conservation phase: The components of the agro-food chain are adequately remunerated and do not depend heavily on subsidies or extraagricultural jobs (Reasonable profitable). The supply chain redundancy concerns the extent to which the different nodes and components of the supply chain are replaceable. Diversity is linked to redundancy especially 
in relation to different sets of skills that can be used to achieve the same result. Another important feature is flexibility, which is the degree to which a supply chain can maintain its function and respond effectively to changes in the scenario through partnerships. It is the ability to set up alternative options, such as alternative infrastructure, logistics or personnel. The availability of human and social capital contributes to flexibility, as well as the remaining pool of ecological, economic, social, physical, institutional and cultural resources on which a community can draw when faced with a shock.

\section{Building a methodological framework for Agro-food chain resilience assessment and its relation with ESS}

In this section, the characteristics of resilient agro-food chains described previously are operationalized by developing a framework that can be used by value chain actors to assess resilience in a given situation and outline the effects on ESS. Involving the key stakeholders through a participatory approach, the framework enables them to both understand and assess the uncertainties the chain is facing while analysing the actions and strategies adopted by the different components of the system in order to build resilience and understand the effects of the resulting dynamic relations and feedbacks in terms of ecosystem services and wider socioeconomic effects. By using this approach, not only is the assessment approach effective for understanding the resilience of an agro-food system, but the process itself can begin to build resilience through broad participation, by developing capacity for complex adaptive systems thinking and learning (Salvia and Quaranta, 2015). This approach also provides the opportunity for actors to develop indicators that are contextually appropriate and for which monitoring is feasible. The proposed framework follows four main steps, depicted below. The different steps of the framework are artificially separated since they are closely related to each other and overlap. The steps are reiterated until a consensus among the stakeholders is reached.

Identifying the adaptive cycle phases of the agro-food chain: The first step consists of a diachronic analysis of the agro-food chain and the wider 
socio-ecological system within which it is based. The analysis should be focused on identifying the main threats and shocks that have affected the agro-food chain and end with the identification of different time periods and their position within the adaptive cycle. The analysis is conducted by using the adaptive cycle heuristic as a guiding tool and with the active participation of key stakeholders.

Describing, for each time period, resilience-ideal behaviour of all components of the agro-food chain, operationalizing them through a set of criteria

Using the time periods identified in the previous step, resilience-ideal behaviours are specified by a set of criteria (Tab. 1). Criteria are identified according to economic, social and natural capital and to the level of capital development (well or poor developed) (Wilson, 2010, Salvia and Quaranta, 2015). They are adapted to the local context and agreed among the stakeholders.

Assessment of the distance between ideal and actual resilience behaviour of the agro-food chain in each time period

The agro-food chain dynamics are described in terms of accumulation and release of the social, natural and economic capitals attached to each resilience ideal-behaviour.

Assessment of the effects of the agro-food chain behaviour on ecosystem services and socio-economic effects

A harmonious development of the three capitals is considered the key for the functioning of the socio-ecological system in which the agro-food chain is embedded. An optimal 'balance' between the three capitals specifying the resilience behaviour enables the socio-ecological system not only to persist but to thrive over time and to provide ecosystem services.

\section{An application of the framework}

The framework has been tested in the Alento basin in Campania, Southern Italy. It covers an area of around 55,000 hectares and includes fertile plains as well as hilly and mountainous areas. Alento's agricultural sector has been in decline for several decades, which has led to high rates of 
land abandonment and a severe reduction is utilized agricultural surface. Olive farming in particular has seen a significant reduction in inland hilly areas as production has moved to the more favourable plains.

The reconstruction of historic shocks and disturbances to the SES and their impact on the local olive oil chain was based on available data and the direct involvement of local stakeholders from the olive sector (farmers, processors and distributors) as well as from the tourism industry. The stakeholders were carefully selected to represent as broad as possible age range, gender balance and business size. In total around 45 stakeholders were involved in 11 informal round table meetings over a nine month period (from June 2017 to February 2018). The stakeholders were first presented with a proposed outline of the phases of the SES's adaptive cycles, as identified by the research group on the basis of documentary sources and a review of the relevant literature, and then invited to give their input to arrive at a definitive description of each phase. 


\begin{tabular}{|c|c|c|c|c|}
\hline & Exploitation phase & Conservation phase & Release phase & Reorganization phase \\
\hline $\begin{array}{l}\text { Strongly developed } \\
\text { social capital }\end{array}$ & $\begin{array}{l}\text { Presence of tight-knit agro-food chain } \\
\text { and rural actors, open dialogue between } \\
\text { stakeholders groups, high diversity, in- } \\
\text { vestment in educational infrastructure } \\
\text { and institutions, measures to preserve } \\
\text { local knowledge }\end{array}$ & $\begin{array}{l}\text { Close interaction between rural peo- } \\
\text { ple and between actors of the agro- } \\
\text { food chains; high diversity; continued } \\
\text { presence of indicators seen in previ- } \\
\text { ous phase }\end{array}$ & $\begin{array}{l}\text { Engagement of elders; incorporation } \\
\text { of traditional cultivation and pro- } \\
\text { cessing techniques with modern } \\
\text { knowledge; investment in education- } \\
\text { al infrastructure and institutions; di- } \\
\text { versity of skills; collaboration be- } \\
\text { tween the actors of the agro-food } \\
\text { chains }\end{array}$ & $\begin{array}{l}\text { Extension and advisory services for } \\
\text { farmers; collaboration between uni- } \\
\text { versities, research centres, and agro- } \\
\text { food chain actors; cooperation and } \\
\text { knowledge sharing }\end{array}$ \\
\hline $\begin{array}{l}\text { Weakly developed } \\
\text { social capital }\end{array}$ & $\begin{array}{l}\text { Outmigration; ageing population; poor } \\
\text { communication between agro-food chain } \\
\text { and rural actors; poor investment in edu- } \\
\text { cation; weak support for local knowledge } \\
\text { preservation }\end{array}$ & $\begin{array}{l}\text { Continued presence of indicators } \\
\text { seen in previous phase }\end{array}$ & $\begin{array}{l}\text { No engagement of elders; no incor- } \\
\text { poration of traditional cultivation and } \\
\text { processing techniques with modern } \\
\text { knowledge; no investment in educa- } \\
\text { tion; low diversity of skills; low col- } \\
\text { laboration along the chains }\end{array}$ & $\begin{array}{l}\text { Absence of extension and advisory } \\
\text { services for farmers; no collaboratior } \\
\text { between universities, research cen- } \\
\text { tres and agro-food chain actors; no } \\
\text { cooperation and knowledge sharing }\end{array}$ \\
\hline $\begin{array}{l}\text { Strongly developed } \\
\text { economic capital }\end{array}$ & $\begin{array}{l}\text { Agro-food actors collaborate with multi- } \\
\text { ple suppliers and many outlets; the com- } \\
\text { ponents of the agro-food chains are di- } \\
\text { verse (different scale, processes etc.) }\end{array}$ & $\begin{array}{l}\text { The component of the agro-food } \\
\text { chain are adequately and equally re- } \\
\text { munerated and do not depend heavi- } \\
\text { ly on subsidies. Presence of partner- } \\
\text { ships; diversity of agro-food chain } \\
\text { components }\end{array}$ & $\begin{array}{l}\text { Diversity of agro-food chain compo- } \\
\text { nents (scales, production systems); } \\
\text { balanced bargaining power within } \\
\text { the agro-food chains; good flow of in- } \\
\text { formation along the chain; record } \\
\text { keeping; baseline knowledge about } \\
\text { the state of the agroecosystem }\end{array}$ & $\begin{array}{l}\text { Ability to organize into grassroots } \\
\text { networks and institutions (co-ops, } \\
\text { farmer's markets etc.); high diversity }\end{array}$ \\
\hline $\begin{array}{l}\text { Weakly developed } \\
\text { economic capital }\end{array}$ & $\begin{array}{l}\text { Agro-food actors rely on a small number } \\
\text { of suppliers and outlets; the components }\end{array}$ & $\begin{array}{l}\text { Agro-food chains components are } \\
\text { not adequately remunerated and/or } \\
\text { differently remunerated; Highly de- }\end{array}$ & $\begin{array}{l}\text { Low diversity; strong bargaining } \\
\text { power of part of the chain over oth- }\end{array}$ & $\begin{array}{l}\text { Inability to organize into grassroots } \\
\text { networks and institutions; low diver- }\end{array}$ \\
\hline
\end{tabular}


13

\begin{tabular}{|c|c|c|c|c|}
\hline & of agro-food chain are homogeneous & $\begin{array}{l}\text { pendent on subsidies; No partner- } \\
\text { ships; low diversity }\end{array}$ & ers; no flow of information & sity; low diversity \\
\hline $\begin{array}{l}\text { Strongly developed } \\
\text { natural capital }\end{array}$ & $\begin{array}{l}\text { Polyculture planting and diversified culti- } \\
\text { vation practices, crop rotation and patch- } \\
\text { iness on managed and unmanaged land, } \\
\text { good water and soil quality and availabil- } \\
\text { ity }\end{array}$ & $\begin{array}{l}\text { Continued presence of indicators } \\
\text { seen in previous phase }\end{array}$ & $\begin{array}{l}\text { Plant varieties and cultivation tech- } \\
\text { niques adapted to local context. Con- } \\
\text { trolled exposure to disturbances in } \\
\text { the form of pest management }\end{array}$ & $\begin{array}{l}\text { High diversity; good water and soil } \\
\text { quality availability; plant varieties } \\
\text { and cultivation techniques adapted } \\
\text { to local context }\end{array}$ \\
\hline $\begin{array}{l}\text { Weakly developed } \\
\text { natural capital }\end{array}$ & $\begin{array}{l}\text { Monoculture, low diversity, farm special- } \\
\text { ization and landscape simplification, soil } \\
\text { and water degradation }\end{array}$ & $\begin{array}{l}\text { Continued presence of indicators } \\
\text { seen in previous phase }\end{array}$ & $\begin{array}{l}\text { Plant varieties and cultivation tech- } \\
\text { niques not adapted to local context. } \\
\text { Natural capital is vulnerable to dis- } \\
\text { turbances }\end{array}$ & $\begin{array}{l}\text { Low diversity; poor water and soil } \\
\text { quality and availabity; Plant varieties } \\
\text { and cultivation techniques not } \\
\text { adapted to local context }\end{array}$ \\
\hline
\end{tabular}

Source: authors based on Salvia and Quaranta, 2015; Wilson, 2010; Cabell and Oelofse, 2012, Stone and Rahimifard (2018) 

The time period chosen was the late 1940s to the present day for two reasons; firstly, because it covered the historical memory of local actors and, secondly, because it marked the departure from traditional agriculture towards significant modernisation.

5.1 The assessment of resilience behaviour and its impact on the ecosystem services along the phases of adaptive cycles in the Alento area

Three main phases have been identified by stakeholders, which contain the most significant social, economic environmental and institutional changes that have profoundly shaped the Alento SES over the last 60-70 years.

"Migration and efficiency imperative" (Release/Reorganization phases) The first time period, 1950 to the end of 1970's, is identified as a progression from a release to a reorganization phase. Paradigm shifts in the model of agricultural production, introduced under both EU and national policies (type and level of farm subsidies), profoundly shape the SES and begin its modernization. The Italian industrial strategy of the time linked farm subsidies to other production industries, especially chemical and mechanical industries. Connection to external markets is weak, despite the fact that emigration guarantees a flow of products towards extra-local and international destinations.

The SES loses a substantial amount of the olive groves that are poorly suited to modernization but sees an intensification and modernization of olive production in the most favourable areas, i.e. on the plains. The system is reorganized by decoupling itself from its natural system (elimination of closed loop farming; external inputs), there is a loss of traditional know-how and the SES becomes increasingly dependent on the upstream (supply of inputs) and downstream (processing, bottling and distribution) of the olive oil chain.

A reduction in available farmland favours increased crop specialisation, or rather the predominance of olive crops. Olive farming becomes more specialized (work calendar adapted to fit around families affected by outmigration) and reduces the diversity of the system. The specialization in the olive sector is transferred to the agri-industrial sector, which is pre- 
dominately based on processing olives and the sector proves fairly profitable with the aid of subsidies. However, mills are conditioned by the local structure of production and have little incentive to innovate. The weakness of the olive oil supply chain relationships results in the production of a semi-finished product destined to be mixed, bottled and marketed outside the SES. This translates into reduced supply chain visibility and agility as well as a weak capacity for collaboration between the different components of the olive oil system that are geographically distant and operate at different scales (small at production level, large at distribution level).

Effects on the ESS: the production function remains fairly constant because the increased yields in the more intensively farmed areas make up for the reduced production in inland areas. The potential opportunities to create added value and/or niche markets are heavily undermined by the outsourcing of bottling and distribution. The abandonment of olive farming on sloping land, where terraces are most common, begins the slow decline of terrace maintenance and the loss of traditional terrace maintenance know-how. The provision of ecosystem services are not negatively impacted during this period, despite increased pressure on the some areas of land from intensive farming practices and the impacts of land abandonment (soil erosion, collapsing of terraces, encroachment of forests posing greater fire risks) in areas of less favourable farm land.

"Local off-farm jobs" - (Exploitation/Conservation phases). The second period, $1980-2000$, saw the growth and consolidation of modernization in agriculture and the emergence of the tourism industry. The construction of a series of dams in the local area increased the availability of water to farmers and boosted other local industries, particularly construction industries.

Intensive olive farming practices increase on the plains. New, non-native olive tree cultivars were introduced in an attempt to increase yields (EU subsidies were coupled to production) and proved to have disastrous effects by producing a lower quality oil and bringing a range a phytosanitary problems and increased use of pesticides to the area. Agricultural production is highly dependent on subsidies and external inputs, which translates into an increased rigidity in the system. The positive feedback be- 
tween subsidy regime, technologies and changes to natural capital (substitution of traditional cultivar) therefore determines a lowering of the SES's capacity in terms of resistance. The specialization of the local manufacturing industry (olive processing accounts for half of the total agro food sector) is high and leaves the agro-food system with low redundancy because of its high dependence of the agro-industrial sector. This aspect determines a high degree of vulnerability in the system. The production of low quality olive oil (undifferentiated product) is absorbed by big national brands. This gives the SES a weak position in panarchy as the value created mainly moves out of the SES.

Effects on the ESS: The continued reduction in UAS (and numbers working in agricultural sector) does not translate into reduced production. In fact, changes to land management mean that olive oil production remains high. Producers sacrifice quality in the name of containing costs, even though this has not been an explicit consumer demand. Adding value, creating rural jobs, local investment and stabilizing population are policy aims (in this phase designation of origin for olive oil is introduced) but do not create effective results.

The fact that EU subsidies are coupled to production acts as a disincentive to farmers to innovate, the effects of which will be clearly seen in the next time period. The SES is poorly connected internally, both geographically (mountain/hilly areas versus the plains) and economically (lack of integration between sectors). There is, however, a tight connection between the production base and the processing sector. In this period, unlike the first, the lack of terrace maintenance, or in some cases their destruction to allow for mechanized farming methods, is manifested in severe processes of erosion and slope instabilities (it is in this period that at regional level a law for intervention in areas at risk of landslides including areas within the Alento SES was set up.)

"Land Abandonment". (Release/Reorganization phases). The third period, mid 1990s to the present day, sees the beginning of a structural crisis in the olive sector. The introduction of the Single Farm Payment Scheme under the 2013 CAP reform meant that subsides no longer bridged the gap between cost of production and market prices. In this period, the SES shows the simultaneous presence of alternative, and in many cases, di- 
vergent trajectories. On the one hand, in fact, the "productivist model" inherited from previous periods persists and continues to push for greater mechanisation and drives competitiveness by seeking to continually reduce production costs whilst, on the other hand, there are farm models pursuing scope economies (qualification of production; agri-tourism enterprises and on-farm sales or in farmer markets).

Social capital is weakened by population ageing and lack of generational change in farming. The outmigration of the most highly educated is somewhat balanced by positive examples of the return of young people to farming as "innovators", who usually invest money coming from other sectors.

A move to organic olive farming, especially in inland hilly areas creates pockets of "resistance" inside the SES. Greater diversity in the system is helped by the creation of a territorial bio-district network in the late 2000 s, which linked organic farms, producer organisations, the local administration, bio-restaurants, eco-tourism operators and consumers (via the GAS Gruppi di Acquisto Solidale - Solidarity Purchasing Groups).

Redundancy in the agro-food sector is further reduced (olive processing accounts for almost $60 \%$ ). The number of olive oil mills located in the hills and mountains is still quite high but they technologically obsolete. The continued presence of local mills, which reduce the waiting time between harvesting and pressing thus producing a better quality olive oil, could prove important should the olive system pivot towards high-quality, low environmental impact product certification status.

Although the processing phase is quite well organized at a local level, the distribution, a high value added activity, remains for the most part outside the area.

Effects on the ESS: Farm diversification and the increased integration of farming and tourism activities slightly increase the opportunity to create added value and to create niche-market opportunities. The adoption of PDO (Protected Designation of Origin) and Organic product certification is hampered by high costs, bureaucratic red tape and scepticism that certification will result in increased market sales. 
Despite signs of budding economic diversification on this period, the consequences of depopulation and abandonment of farming seen over the past has deprived the socio-ecological system of the workforce and the skills necessary to maintain traditional land management practices. As a result soil erosion and the risk of landslides remain high and the impoverishment of landscape quality negatively impacts other sectors, especially the tourism industry. In addition to its environmental impacts, emigration has had serious repercussions on the social and economic capital of the Alento basin, jeopardizing the capacity of the agricultural system to produce high quality local food (Quaranta and Salvia, 2014).

\section{Key findings}

Loss of the agro-food chain's visibility. The effects of the cost-price squeeze on farmers (falling commodity prices and rising cost of production) are exacerbated by the geographical distance of a part of the agrofood chain, which contributes to an imbalance in terms of the bargaining power of some parts of the chain over others. The visibility of the agrofood chain, or rather the knowledge of the status of operating assets and the environment (Pettit et al., 2010), recognised as an important feature of chain resilience as it is based on close collaboration between suppliers and clients, and that in the proposed framework should represent an integral component in the functioning of the agro-food chain in the phases release/reorganisation, is consistently weak in the SES, shown by very poor information sharing between production, processing, bottling and distribution. This aspect proved to be particularly crucial in the management of the relationship with end consumers, predominately the domain of the distribution sector. The production base, driven exclusively by policy decisions (stimulus to increase productivity) was not able to grasp the changing nature of demand. The choice to switch to non-traditional cultivars, which led to an impoverishment of both the quality of oil and natural capital seeing as the new cultivars were not coupled with the natural resources, is a clear example of the system's inability to incorporate feedbacks coming from consumers, who were increasingly gravitating towards traditional local products.

Another key factor to resilience, connectedness, which should be kept under close control especially in the exploitation phase, reflects the trend 
seen for visibility, or rather it is a direct consequence of this trend. The agricultural component, and therefore the connected socio-ecological system, is completely dependent on external actors, both downstream, for the marketing of the end product, and upstream, for agricultural inputs, highlighting a vulnerability that the socio-ecological system has only recently tried to mitigate.

Colloboration between different parts of the chain. To respond to the problem of unequal bargaining power in the chain and to bring back added value within the SES, relocalisation initiatives were started (the food district, solidarity purchasing groups, adoption of territorial quality branding) that rely on collaboration between the different actors in the agrofood chain, and also extend to include the cooperation of other territorial actors (tourism sector, schools etc.), in the case of the food district, and end consumers in the case of the solidarity purchasing groups. Collaboration, therefore, which ought to be increased in the release/reorganisation phase, begins to be considered as a strategic tool to reduce the imbalances inside the agro-food chain, as similarly seen in other contexts (Leat and Revoredo-Giha, 2013). In the case of Alento, this approach has resulted in improved economic performance in some firms, territorial/landscape requalification and the transfer of better skills. It has also sparked new partnerships with the tourism sector. In reality, however, as the case under study shows, access to this strategy is limited to younger, more dynamic firms that receive capital investment from external sectors. As a result, a large part of the firms operating in marginal areas are excluded for want of the necessary resources (human capital/ financial capital etc.)

As Lamine (2015, p.55) points out "The frequent focus on alternative agrifood systems, which differ radically from the mainstream, does not help to develop pathways towards sustainability and resilience for less alternative institutions and actors".

Difficulty in up-scaling and exceeding thresholds. The agro-food chain and, more generally the socio-ecological system under study, therefore shows an intrinsic difficulty in up-scaling and out-scaling processes. This is a common case in many marginal rural areas (Bock, 2016) that have exceeded critical thresholds in terms of demographics, because of population ageing and out-migration trends (predominately the young and most 
educated) and in terms of the deactivation of farming activities and, therefore, the strength of the production base. In light of this, relying solely on the territorial system's capacity for innovation could prove ineffective. A more suitable approach could be in line with that suggested by Lamine $(2015$, p. 56$)$, of a "territorial agrifood system capable of dealing with the agriculture-food-environment reconnections should consider the diversity of initiatives in agrifood systems, as well as their possible complementarities and the conditions that favour these complementarities".

Role of the Consumer. Consumer choices can play a key role in guiding the system. Solidarity purchasing groups and short chains in general have played a crucial role in the Alento SES as they connected the olive oil chain to urban areas where demand is high for quality products of trusted geographical origin. Consumers are active members in what has been defined as the "food from somewhere" (Campbell, 2009) where efforts are being made to recognize the social and ecological feedbacks between bases of production and points of consumption.

\section{Conclusion}

The objective of the proposed framework is to analyse the dynamics of an agro-food chain, in our case an olive oil chain, in light of its capacity to be resilient and at the same time guarantee the supply of ESS.

Agricultural ecosystems and their capacity to generate ESS are not found in a vacuum but are determined by and are the result of actions that involve other actors (economic, social and institutional), who may be at a spatial and temporal distance. The farmers who, through their choices, directly impacts the ecosystem is not, therefore, solely responsible for the management of the ecosystem itself. To this end, analysing the resilience of the agro-food system by adopting a socio-ecological system perspective proves not only useful in analysing the different mechanisms put in place by the agro-food chain in the different phases considered to be key to the evolution of the SES, but also shifts the focus of the analysis. In fact, this approach which identifies the characteristics and the trajectories of the socio-economic and institutional actors, the interdependencies and the methods of coordination they have implemented over time and their 
implications for the other components of the SES, moves away from an exclusively economic interpretation to focus on their social and environmental implications (Ericksen 2008).

Therefore, analysing strategies for agro-food chain resilience and its relationship to ecosystem services should be seen as a key objective for research and, especially, for policy making. The Common Agricultural Policy (CAP) has addressed this issue (the multifunctionality of agriculture) to some extent through different instruments aimed at protecting (e.g. Natura 2000) and provisioning (e.g. cross-compliance and agrienvironmental Schemes AES) agricultural public goods, as farmers have to be encouraged to pursue certain farming practices in order to maintain landscape features, restore specific habitats, or to manage natural resources such as water and soils. However, despite the fact that landscape preservation is included as an objective in the CAP, as the analysis carried out has shown, an approach based solely on agriculture can prove insufficient. Indeed, the CAP incentives cannot guarantee the survival of farming systems if not coupled and coordinated with mechanisms from within the whole of the agro-food chain. The experience of the Corporate Ecosystem Services Review promoted by the World Resources Institute, aiming at providing guidelines for Identifying Business Risks \& Opportunities Arising from Ecosystem Change (https://www.wri.org/publication/corporateecosystem-services-review), can prove useful in involving the whole chain in sharing responsibility.

Furthermore, it is important to point out how adopting the framework, alongside normal chain analysis, can prove useful in helping socioecological systems to learn from the past and use this shared and holistic knowledge to define new, sustainable trajectories for the future.

ACKNOWLEDGEMENT: The study is partially funded by iSQAPER project, funded by the European Union's Horizon 2020 Programme for research \& innovation under grant agreement no 635750

\section{REFERENCES}


Adger, W. N. (2000). Social and ecological resilience: are they related?. Progress in human geography, 24(3), 347-364.

Babu, S. C., \& Blom, S. (2014). Capacity development for resilient food systems: issues, approaches, and knowledge gaps (Vol. 6). Intl Food Policy Res Inst.

Berkes, F., \& Folke, C. (1998). Linking social and ecological systems for resilience and sustainability. Linking social and ecological systems: management practices and social mechanisms for building resilience, 1(4).

Berkes, F., \& Ross, H. (2016). Panarchy and community resilience: Sustainability science and policy implications. Environmental Science \& Policy, 61, 185-193.

Biggs, R., Schlüter, M., \& Schoon, M. L. (Eds.). (2015). Principles for building resilience: sustaining ecosystem services in social-ecological systems. Cambridge University Press.

Bolwig, S., Ponte, S., Du Toit, A., Riisgaard, L., \& Halberg, N. (2010). Integrating poverty and environmental concerns into value-chain analysis: a conceptual framework. Development Policy Review, 28(2), 173-194.

Bugalho, M. N., Caldeira, M. C., Pereira, J. S., Aronson, J., \& Pausas, J. G. (2011). Mediterranean cork oak savannas require human use to sustain biodiversity and ecosystem services. Frontiers in Ecology and the Environment, 9(5), 278-286.

Cabell, J. F., \& Oelofse, M. (2012). An indicator framework for assessing agroecosystem resilience. Ecology and Society, 17(1).

Campbell, H. (2005). The rise and rise of EurepGAP: European (re) invention of colonial food relations. International Journal of Sociology of Agriculture and Food, 13(2), 6-19.

Campbell, H. (2009). Breaking new ground in food regime theory: corporate environmentalism, ecological feedbacks and the 'food from somewhere'regime?. Agriculture and Human Values, 26(4), 309. 
Carpenter, S., Walker, B., Anderies, J. M., \& Abel, N. (2001). From metaphor to measurement: Resilience of what to what? Ecosystems 4 (8): 765781.

Fondazione Campagna Amica, Coldiretti (2018). I Sigilli di Campagna Ami$\mathrm{ca}$, la biodiversità contadina, Giunti Editore. https://www.campagnamica.it/category/sigilli/

Costanza, R., d'Arge, R., De Groot, R., Farber, S., Grasso, M., Hannon, B., ... \& Raskin, R. G. (1997). The value of the world's ecosystem services and natural capital. Nature, 387(6630), 253.

Darnhofer, I., Fairweather, J., \& Moller, H. (2010b). Assessing a farm's sustainability: insights from resilience thinking. International journal of agricultural sustainability, 8(3), 186-198.

Darnhofer, I. (2014). Resilience and why it matters for farm management. European Review of Agricultural Economics, 41(3), 461-484.

Darnhofer, I., Lamine, C., Strauss, A., \& Navarrete, M. (2016). The resilience of family farms: Towards a relational approach. Journal of Rural Studies, 44, 111-122.

Debolini, M., Marraccini, E., Dubeuf, J. P., Geijzendorffer, I. R., Guerra, C., Simon, M., ... \& Napoléone, C. (2018). Land and farming system dynamics and their drivers in the Mediterranean Basin. Land Use Policy, 75, 702710.

Dissart, J. C., \& Vollet, D. (2011). Landscapes and territory-specific economic bases. Land Use Policy, 28(3), 563-573.

Ericksen, P. J. (2008). Conceptualizing food systems for global environmental change research. Global environmental change, 18(1), 234-245.

Folke, C., Carpenter, S. R., Walker, B., Scheffer, M., Chapin, T., \& Rockström, J. (2010). Resilience thinking: integrating resilience, adaptability and transformability. Ecology and society, 15(4).

Gunderson, L. H. \& Holling, C. S. (2002). Resilience and adaptive cycles. In: Panarchy: Understanding Transformations in Human and Natural Systems, 25-62. 
Himanen, S. J., Rikkonen, P., \& Kahiluoto, H. (2016). Codesigning a resilient food system. Ecology and Society, 21(4).

Hodbod, J., Barreteau, O., Allen, C., \& Magda, D. (2016). Managing adaptively for multifunctionality in agricultural systems. Journal of environmental management, 183, 379-388.

Holling, C. S. (1973). Resilience and stability of ecological systems. Annual review of ecology and systematics, 4(1), 1-23.

Huang, J., Tichit, M., Poulot, M., Darly, S., Li, S., Petit, C., \& Aubry, C. (2015). Comparative review of multifunctionality and ecosystem services in sustainable agriculture. Journal of environmental management, 149, 138-147.

Hubeau, M., Marchand, F., Coteur, I., Mondelaers, K., Debruyne, L., \& Van Huylenbroeck, G. (2017). A new agri-food systems sustainability approach to identify shared transformation pathways towards sustainability. Ecological Economics, 131(C), 52-63.

Huylenbroeck, G., Vandermeulen, V., Mettepenningen, E., \& Verspecht, A. (2007). Multifunctionality of agriculture: a review of definitions, evidence and instruments. Living Reviews in Landscape Research, 1(3), 1-43.

Kamalahmadi, M., \& Parast, M. M. (2016). A review of the literature on the principles of enterprise and supply chain resilience: Major findings and directions for future research. International Journal of Production Economics, 171, 116-133.

Knickel, K., Zemeckis, R., \& Tisenkopfs, T. (2013). A critical reflection of the meaning of agricultural modernization in a world of increasing demands and finite resources. In 6th International Scientific Conference'Rural Development, 28-29.

Knickel, K., Redman, M., Darnhofer, I., Ashkenazy, A., Calvao Chebach, T., Šūmane, S., Tisenkopfs, T., Zemeckis, R., Atkociuniene, V., Rivera, M., Strauss, A., Kristensen, L.S., Schiller, S., Koopmans M., \& Rogge, E. (2018). Between aspirations and reality: Making farming, food systems and rural areas more resilient, sustainable and equitable. Journal of Rural Studies, 59, 197-210. 
Lamine, C. (2015). Sustainability and resilience in agrifood systems: reconnecting agriculture, food and the environment. Sociologia ruralis, 55(1), 41-61.

Leat, P., \& Revoredo-Giha, C. (2013). Risk and resilience in agri-food supply chains: the case of the ASDA PorkLink supply chain in Scotland. Supply Chain Management: An International Journal, 18(2), 219-231.

Pettit, T. J., Croxton, K. L., \& Fiksel, J. (2013). Ensuring supply chain resilience: development and implementation of an assessment tool. Journal of business logistics, 34(1), 46-76.

Pinto-Correia, T., \& Vos, W. (2004). Multifunctionality in Mediterranean landscapes-past and future. The new dimensions of the European landscape, 4, 135-164.

Ponomarov, S. Y., \& Holcomb, M. C. (2009). Understanding the concept of supply chain resilience. The international journal of logistics management, 20(1), 124-143.

Potter, C., \& Tilzey, M. (2005). Agricultural policy discourses in the European post-Fordist transition: neoliberalism, neomercantilism and multifunctionality. Progress in Human geography, 29(5), 581-600.

Quaranta, G., \& Salvia, R. (2014). Sustainability patterns and policy fit: evidences from a mixed approach applied in a Euro-Mediterranean area (Alento Basin, Campania Region, Italy). Rivista di Studi sulla sostenibilità, DOI: $10.3280 /$ riss2014-002005

Rodríguez-Entrena, M., Colombo, S., \& Arriaza, M. (2017). The landscape of olive groves as a driver of the rural economy. Land Use Policy, 65, 164175.

Salvia, R., \& Quaranta, G. (2015). Adaptive cycle as a tool to select resilient patterns of rural development. Sustainability, 7(8), 11114-11138.

Schaller, L., Targetti, S., Villanueva, A. J., Zasada, I., Kantelhardt, J., Arriaza, M., ... \& Majewski, E. (2018). Agricultural landscapes, ecosystem services and regional competitiveness-Assessing drivers and mechanisms in nine European case study areas. Land Use Policy, 76, 735-745. 
Scott, M. (2013). Resilience: a conceptual lens for rural studies?. Geography Compass, 7(9), 597-610.

Sharpley, R., \& Vass, A. (2006). Tourism, farming and diversification: An attitudinal study. Tourism management, 27(5), 1040-1052.

Stone, J., \& Rahimifard, S. (2018). Resilience in agri-food supply chains: a critical analysis of the literature and synthesis of a novel framework. Supply Chain Management: An International Journal.

Tempesta, T., Giancristofaro, R. A., Corain, L., Salmaso, L., Tomasi, D., \& Boatto, V. (2010). The importance of landscape in wine quality perception: An integrated approach using choice-based conjoint analysis and combination-based permutation tests. Food Quality and Preference, 21(7), 827-836.

Tendall, D. M., Joerin, J., Kopainsky, B., Edwards, P., Shreck, A., Le, Q. B., ... \& Six, J. (2015). Food system resilience: defining the concept. Global Food Security, 6, 17-23.

Torralba, M., Fagerholm, N., Burgess, P. J., Moreno, G., \& Plieninger, T. (2016). Do European agroforestry systems enhance biodiversity and ecosystem services? A meta-analysis. Agriculture, ecosystems \& environment, 230, 150-161.

Vroegindewey, R., \& Hodbod, J. (2018). Resilience of Agricultural Value Chains in Developing Country Contexts: A Framework and Assessment Approach. Sustainability, 10(4), 916.

Walker, B., Holling, C. S., Carpenter, S. R., \& Kinzig, A. (2004). Resilience, adaptability and transformability in social-ecological systems. Ecology and society, 9(2).

Wilson, G. (2010). Multifunctional 'quality' and rural community resilience. Transactions of the Institute of British Geographers, 35(3), 364-381.

Wilson, G. A. (2012). Community resilience, globalization, and transitional pathways of decision-making. Geoforum, 43(6), 1218-1231.

Wilson, G., Quaranta, G., Kelly, C., \& Salvia, R. (2016). Community resilience, land degradation and endogenous lock-in effects: evidence from 
the Alento region, Campania, Italy. Journal of Environmental Planning and Management, 59(3), 518-537. 